\title{
Expression of the Bcl-3 proto-oncogene suppresses p53 activation
}

\author{
David Kashatus, ${ }^{1,2}$ Patricia Cogswell, ${ }^{2}$ and Albert S. Baldwin ${ }^{1,2,3,4}$ \\ ${ }^{1}$ Curriculum in Genetics and Molecular Biology, ${ }^{2}$ Lineberger Comprehensive Cancer Center, and ${ }^{3}$ Department of Biology, \\ University of North Carolina School of Medicine, Chapel Hill, North Carolina 27599, USA
}

\begin{abstract}
While Bcl-3 expression in cancer was originally thought to be limited to B-cell lymphomas with a 14;19 chromosomal translocation, more recent evidence indicates that expression of this presumptive oncoprotein is significantly more widespread in cancer. However, an oncogenic role for Bcl-3 has not been clearly identified. Experiments presented here indicate that Bcl-3 is inducible by DNA damage and is required for the induction of $\mathrm{Hdm} 2$ gene expression and the suppression of persistent p53 activity. Furthermore, constitutive expression of Bcl-3 suppresses DNA damage-induced $\mathrm{p} 53$ activation and inhibits p53-induced apoptosis through a mechanism that is at least partly dependent on the up-regulation of $\mathrm{Hdm} 2$. The results provide insight into a mechanism whereby altered expression of Bcl-3 leads to tumorigenic potential. Since Bcl-3 is required for germinal center formation, these results suggest functional similarities with the unrelated Bcl-6 oncoprotein in suppressing potential p53-dependent cell cycle arrest and apoptosis in response to somatic hypermutation and class switch recombination.
\end{abstract}

[Keywords: Apoptosis; Bcl-3; Hdm2; NF-кB; p53]

Supplemental material is available at http://www.genesdev.org.

Received July 5, 2005; revised version accepted November 17, 2005.

Bcl-3 was first identified through cloning of the $t(14 ; 19)$ breakpoint junction, which occurs in a subset of B-cell chronic lymphocytic leukemias (B-CLLs) (McKeithan et al. 1987). A member of the ankyrin-repeat-containing ІкB family of NF-кB inhibitors (Hayden and Ghosh 2004), Bcl-3 is apparently unique in that, unlike other IкBs, its localization is nuclear and it contains a transactivation domain. Studies have shown that Bcl-3 preferentially binds to NF-кB p50 and p52 homodimers (Bours et al. 1993; Nolan et al. 1993) and, through its interaction with coactivators such as CBP/p300, SRC-1, and Tip60 (Na et al. 1998; Dechend et al. 1999/ and corepressors such as HDAC1 (Wessells et al. 2004), can both activate and repress transcription of target genes. Importantly, genetic knockout of Bcl-3 leads to impaired microarchitecture in spleen and lymph nodes with associated germinal center defects (Franzoso et al. 1997; Schwarz et al. 1997).

Relatively high levels of Bcl-3 expression in certain B-CLLs suggests that it may play a direct role in oncogenesis. In this regard, expression of Bcl-3 is sufficient to transform NIH3T3 cells (Viatour et al. 2004). Importantly, Bcl-3 has now been shown to be more widely expressed in cancer, with expression in a significant number of breast cancers (Cogswell et al. 2000), naso-

${ }^{4}$ Corresponding author.

E-MAIL abaldwin@med.unc.edu; FAX (919) 966-0444.

Article published online ahead of print. Article and publication date are at http://www.genesdev.org/cgi/doi/10.1101/gad.1352206. pharyngeal carcinomas (Thornburg et al. 2003), lymphomas (Canoz et al. 2004), and hepatocellular carcinomas and pancreatic cancers (B. O'Neil, unpubl.). The findings that Bcl-3, in complex with p52, can promote transcription of the genes encoding the cell cycle regulator cyclin $\mathrm{D} 1$ and the anti-apoptotic Bcl-2 protein suggest one potential oncogenic mechanism (Westerheide et al. 2001; Viatour et al. 2003), but a more complete understanding of the role of Bcl-3 in human cancers is still lacking.

p53 is a crucial guardian of genomic integrity, and its importance as a tumor suppressor is underscored by the fact that it is either mutated or otherwise dysregulated in the majority of human cancers (Vousden and Lu 2002; Vousden and Prives 2005). Normally, p53 remains at low levels through its interaction with the E3 ubiquitin ligase, $\mathrm{Hdm} 2$. Upon cellular stress or oncogene activation, this interaction is disrupted and p53 rapidly accumulates in the nucleus, where it can activate a number of target genes, including the cyclin-dependent kinase inhibitor p21 (el-Deiry et al. 1993), pro-apoptotic genes Noxa and Puma (Oda et al. 2000; Nakano and Vousden 2001; Yu et al. 2001), and its own inhibitor Hdm2 (Barak et al. 1993). Recent evidence also suggests that p53 can play a direct apoptotic role in the mitochondria, independent of its transcriptional function (Chipuk et al. 2004). Ultimately, depending on the type and intensity of the signal, as well as the cellular context, p53 stabilization results in either cell cycle arrest or apoptosis. Loss of p53 function, through either mutation or an alternative 
mechanism such as overexpression of $\mathrm{Hdm} 2$, leads to dysregulated growth, protection against apoptosis, and genomic instability, allowing for the accumulation of secondary mutations (Bond et al. 2005; Vousden and Prives 2005).

Based on the ability of NF-кB to regulate cell death pathways (Ghosh and Karin 2002; Kucharczak et al. 2003) and on recent studies that suggest a link between Bcl-3 and the DNA damage response (Boulton et al. 2002; Watanabe et al. 2003), we have investigated a potential role for Bcl-3 in regulating the apoptosis response to DNA damage. We find that Bcl-3 is transiently up-regulated by DNA damage and that constitutive expression of Bcl-3 in MCF-7 cells leads to a strong suppression of DNA damage-induced cell death without a significant effect on NF-кB-regulated anti-apoptotic genes. Importantly, Bcl-3 expression leads to suppression of p53 induction following DNA damage, resulting in the inhibition of expression of the p53 target genes Noxa and Puma. Analysis of Bcl-3-null mouse embryonic fibroblasts (MEFs) or cancer cells knocked down for Bcl-3 reveals that loss of Bcl-3 leads to an enhanced p53 response. One mechanism by which this inhibition occurs is through Bcl-3-mediated induction of the p53 inhibitor $\mathrm{Hdm} 2$. Both stable and transient overexpression of Bcl-3 leads to increased $\mathrm{Hdm} 2$ expression, and small interfering RNA (siRNA)-mediated knockdown of Bcl-3 blocks expression of $\mathrm{Hdm} 2$. Analysis of Bcl-3-null fibroblasts reveals that $\mathrm{Bcl}-3$ is required for the induction of $\mathrm{Mdm} 2$ gene expression and for limiting the p53 activation response. Disruption of the p53-Hdm2 interaction in Bcl3 -expressing cells functions to rescue the p53 inhibition and apoptotic response. Furthermore, the data support a model whereby Bcl-3, like the unrelated oncoprotein Bcl6, functions to suppress p53-dependent cell cycle arrest and apoptosis in germinal center B cells undergoing somatic mutation and class switch recombination. Our results provide significant new insights into oncogenic mechanisms associated with $\mathrm{Bcl}-3$ and provide evidence that Bcl-3 is required for p53 to induce expression of Hdm2 gene expression.

\section{Results}

Elevated Bcl-3 expression inhibits DNA damage-induced apoptosis

In addition to its relatively high expression in B-CLLs carrying the $\mathrm{t}(14 ; 19)$ translocation, Bcl-3 has also been found to be elevated in a number of other human cancers, including nasopharyngeal carcinoma (Thornburg et al. 2003), breast cancer (Cogswell et al. 2000), lymphoma (Canoz et al. 2004), and hepatocellular carcinoma (B. $\mathrm{O}^{\prime}$ Neil, unpubl.). To understand the consequences of Bcl-3 constitutive expression and to investigate its potential role in driving oncogenesis, we engineered the MCF-7 breast cancer cell line to express relatively high levels of Bcl-3 (MCF-7B). Expression of Bcl-3 in the MCF$7 \mathrm{~B}$ cells is comparable to its expression in several cancer cell lines, including Karpas 299 cells, which have been previously reported to express high levels of Bcl-3 (Nishikori et al. 2003), and the fibrosarcoma line, HT-1080 (Fig. 1A).

One characteristic shared by many human cancers is the inability to appropriately respond to genomic insults. To determine if Bcl-3 overexpression might contribute to this deficiency, we treated MCF-7 and MCF-7B cells with either UV-C or the DNA damage-inducing drug cisplatin and measured the apoptotic response. Intriguingly, MCF-7B cells exhibit a significant resistance to DNA damage-induced cell death (Fig. 1B). As expected, the DNA damage-induced cell death in the parental MCF-7 line is dependent on p53 activity, as cotreatment with the p53 inhibitor pifithrin- $\alpha$ (Komarov et al. 1999) inhibits the apoptotic response following UV treatment (Fig. 1C).

Notably, the protective effects of Bcl-3 do not extend to non-p53-dependent inducers of apoptosis, as treatment with the drug staurosporine results in similar levels of apoptosis in both MCF-7 and MCF-7B cells (Supplementary Fig. 1A). Somewhat surprisingly, no increase was observed in the MCF-7B cells of expression of

A

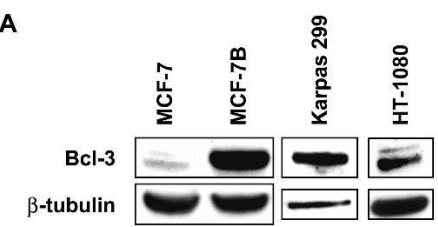

B

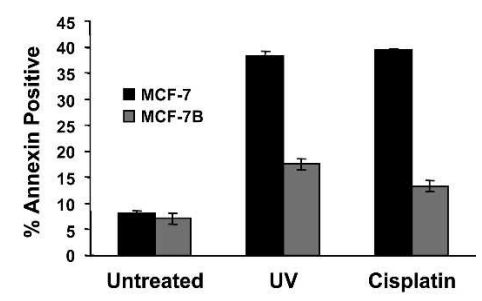

C

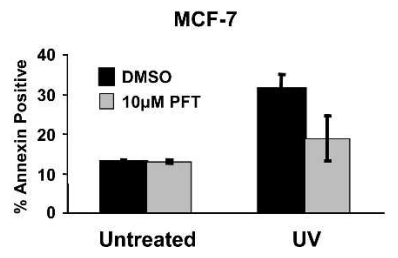

Figure 1. Overexpression of Bcl-3 inhibits DNA damage-induced apoptosis. (A) Expression of Bcl-3 in MCF-7, MCF-7B, Karpas 299, and HT-1080 cells. Western blots of extracts from indicated cell lines were probed with antibodies against Bcl-3 and $\beta$-tubulin. (B) MCF-7B cells are protected against DNA damage-induced apoptosis. MCF-7 and MCF-7B cells were left untreated or were treated with $40 \mathrm{~J} / \mathrm{m}^{2} \mathrm{UV}-\mathrm{C}$ or $10 \mu \mathrm{g} / \mathrm{mL}$ cisplatin as indicated. Eighteen hours after treatment, apoptosis was measured by flow cytometric analysis of Annexin-V staining. (C) UV-induced apoptosis in MCF-7 cells is p53 dependent. MCF-7 cells were treated with DMSO, $10 \mu \mathrm{M}$ pifithrin- $\alpha, 40$ $\mathrm{J} / \mathrm{m}^{2} \mathrm{UV}$-C plus DMSO, or $40 \mathrm{~J} / \mathrm{m}^{2} \mathrm{UV}-\mathrm{C}$ plus $10 \mu \mathrm{M}$ pifithrin- $\alpha$ as indicated. Eighteen hours after treatment, apoptosis was measured by flow cytometric analysis of Annexin-V staining. 
known anti-apoptotic genes that are reportedly regulated by NF-кB following treatment with UV or cisplatin (D. Kashatus, unpubl.). As such, we sought to investigate other potential mechanisms for this anti-apoptotic activity.

\section{Bcl-3 inhibits the p53 response to DNA damage}

As p53 is a critical mediator of the apoptotic response following DNA damage (Vousden and Prives 2005), and given that DNA damage-induced apoptosis in MCF-7 cells is p53 dependent (Fig. 1C), we sought to investigate whether expression or activation of this tumor suppressor is affected by constitutive expression of Bcl-3. Interestingly, Bcl-3 protein levels increase transiently between 2 and 6 h following UV treatment in the parental MCF-7 cells, returning to basal levels by $24 \mathrm{~h}$, suggesting that this oncoprotein may have a role in the UV response. The increase in Bcl-3 protein is likely to be at the level of protein stability as we detect no increase in Bcl-3 mRNA following UV treatment (D. Kashatus, unpubl.). The transient nature of the response is consistent with the report that p53 can negatively regulate $\mathrm{Bcl}-3$ protein (Rocha et al. 2003), as the loss of Bcl-3 coincides with the accumulation of p53.

As expected, p53 is induced in the parental MCF-7 cells in response to UV treatment, with peak levels reached $\sim 8 \mathrm{~h}$ following treatment. Intriguingly, the p53 response in MCF-7B cells is significantly muted, with peak p53 protein levels being considerably lower than in the parental cells (Fig. 2A). This down-regulation of the p53 response is not correlated with reduced p53 mRNA levels (Fig. 2B). To ensure that the resulting suppression of the p53 response by Bcl-3 is not a consequence of creating and selecting stable cells, we transiently expressed Flag-tagged Bcl-3 in parental MCF-7 cells and treated the cells with UV. Consistent with the results from the stable lines, increased expression of Bcl-3 leads to a decrease in the levels of p53 protein $4 \mathrm{~h}$ following UV treatment (Fig. 2C). Further, we transfected expression vectors for p53 plus Bcl-3 or p53 plus empty vector along with the pg13 p53 responsive reporter (el-Deiry et al. 1993) into parental MCF-7 cells to test p53 transcriptional activity in the presence of excess Bcl-3. As expected, p53 activated the luciferase reporter while coexpression of Bcl-3 partially suppressed this response (Fig. 2D). Basal p53 activity is very low in these cells, thus any decrease in basal p53 activity upon Bcl-3 overexpression falls below the detection limit of the assay. Taken together, these results indicate that expression of Bcl-3 can suppress the activation of p53 (see Discussion).
A

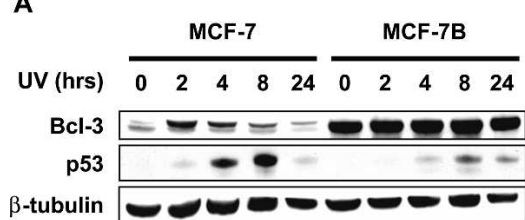

B p53 mRNA levels

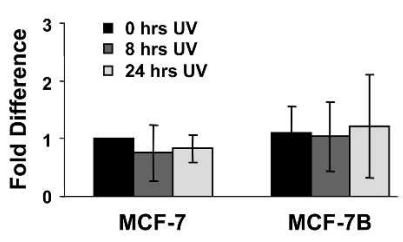

C

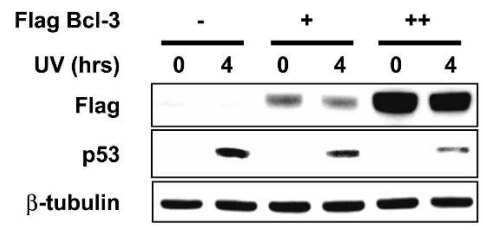

D

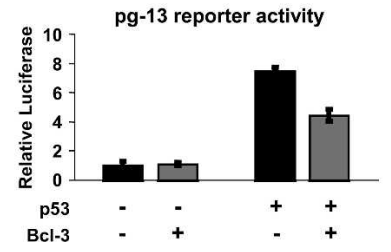

E
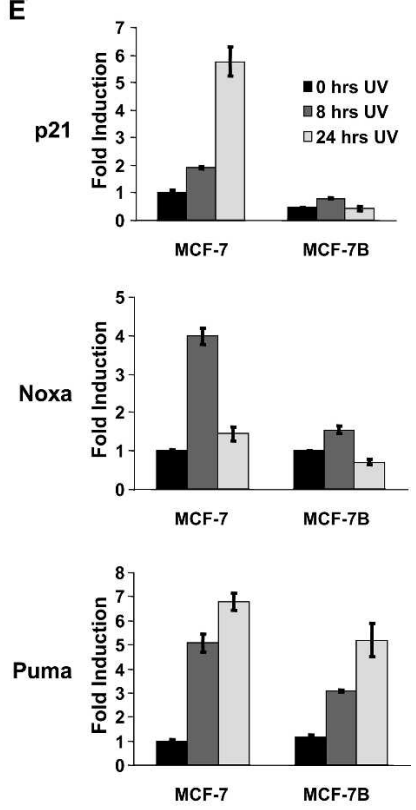

Figure 2. Bcl-3 overexpression inhibits DNA damageinduced p53 activity. (A) UV-induced p53 protein levels are reduced in MCF-7B cells. MCF-7 and MCF-7B cells were treated with $40 \mathrm{~J} / \mathrm{m}^{2} \mathrm{UV}-\mathrm{C}$ for the indicated times, and Western analysis was performed on wholecell extracts using antibodies against Bcl-3, p53, and $\beta$-tubulin. (B) Overexpression of Bcl-3 does not affect p53 mRNA levels. MCF-7 and MCF-7B cells were treated with $40 \mathrm{~J} / \mathrm{m}^{2} \mathrm{UV}-\mathrm{C}$ for the indicated times, and relative expression of p53 was measured by quantitative real-time PCR. (Lane 1) Expression levels were normalized to expression of glucuronidase- $\beta$, and the values represent the fold increase or decrease relative to untreated MCF-7 cells. (C) Transient expression of Bcl-3 leads to decreased p53 protein levels following UV treatment. MCF-7 cells were transfected with either empty vector or 2 or $4 \mu \mathrm{g}$ of pCMV-Flag-Bcl-3. Two days after transfection, the cells were left untreated or were treated with $50 \mathrm{~J} / \mathrm{m}^{2} \mathrm{UV}$-C for $4 \mathrm{~h}$, and Western analysis was performed with antibodies against the Flag epitope, p53, or $\beta$-tubulin. $(D)$ Transient expression of Bcl-3 inhibits p53 transcriptional activity. MCF-7 cells were transfected with $50 \mathrm{ng}$ of pg-13-luciferase and $5 \mathrm{ng}$ of renilla luciferase plus 100 ng of pCMV-Flag-Bcl-3 and pCMV-Flag-p53 where indicated. Firefly luciferase activity was measured and normalized to renilla luciferase. (Lane 1) Values represent fold increase over basal activity. (E) DNA damageinduced expression of p53 target genes is lost in MCF7B cells. MCF-7 and MCF-7B cells were treated with 40 $\mathrm{J} / \mathrm{m}^{2} \mathrm{UV}-\mathrm{C}$ for the indicated times, and relative expression of p21, Noxa, and Puma was measured by quantitative real-time PCR. (Lane 1) Expression levels were normalized to expression of glucuronidase- $\beta$, and the values represent the fold increase or decrease relative to untreated MCF-7 cells. 
To determine the effect of Bcl-3 expression on the induction of p53 target genes, real-time quantitative PCR was performed on cDNA generated from MCF-7 and MCF-7B cells exposed to UV. The cyclin-dependent kinase inhibitor p21 is an important target of p53 that functions in p53-dependent cell cycle arrest. Real-time PCR analysis of p21 mRNA indicates that Bcl-3 expression leads to an almost complete loss of $\mathrm{p} 21$ induction by UV (Fig. 2E). Other important gene targets of p53 encode pro-apoptotic proteins, including Noxa and Puma, members of the BH3-only class of Bcl-2 homologs. Recent knockouts of these p53 targets indicate that they are essential effectors of p53-dependent apoptosis (Jeffers et al. 2003; Villunger et al. 2003). Analysis of these gene products indicates that, as with $\mathrm{p} 21$, constitutive Bcl-3 expression leads to a loss of their induction following UV treatment (Fig. 2E). Notably, while p21 and Noxa expression are almost completely abrogated, the levels of Puma are only modestly inhibited, consistent with reports of p53-dependent and p53-independent induction of this gene (Jeffers et al. 2003).

Knockdown or knockout of Bcl-3 expression leads to enhanced p53 activation following DNA damage

To further analyze the role of Bcl-3 in DNA damageinduced p53 function, we analyzed the outcome of knockdown of Bcl-3 in HT1080 fibrosarcoma cells since these cells express a functional form of p53 (Suzuki et al. 2003) as well as elevated Bcl-3. siRNA against Bcl-3, but not the control siRNA, leads to a near complete loss of the faster migrating form of Bcl-3 and to a significant reduction in the slower migrating form. Importantly, knockdown of expression of Bcl-3 generates enhanced basal and UV-induced p53 expression. These results indicate that elevated expression of Bcl-3, at least in certain p53 wild-type cancer cells, represses the activation potential of $\mathrm{p} 53$. To extend these studies and to analyze the outcome of loss of Bcl-3 through a mechanism independent of siRNA knockdown, we analyzed the p53 response in $\mathrm{Bcl}-3^{+/+}$and $\mathrm{Bcl}-3^{-/-}$primary MEFs. Exposure of these cells to UV leads to the expected p53 response in wild-type cells, but to elevated levels of p53 at the 24-h time point in Bcl-3-null cells (Fig. 3B). Consistent with the observed p53 response in Bcl-3-null fibroblasts, treatment of these cells with UV leads to an increase in apoptosis compared with the wild-type cells (Fig. 3C). Importantly, cotreatment with pifithrin- $\alpha$ leads to a reduction in the apoptotic response to UV in the Bcl- $3^{-/-}$cells, indicating that this response is at least partly dependent on p53 activity (Fig. 3C). In addition, loss of Bcl-3 does not sensitize MEFs to TNF $\alpha$-induced apoptosis (Supplementary Fig. 1B) consistent with the idea that the protection it provides is specific for $\mathrm{p} 53$-dependent inducers of apoptosis. These results are consistent with a role for Bcl-3 in suppressing the p53 activation response, both when Bcl-3 is constitutively expressed at high levels and when Bcl-3 is transiently induced in response to DNA damage.
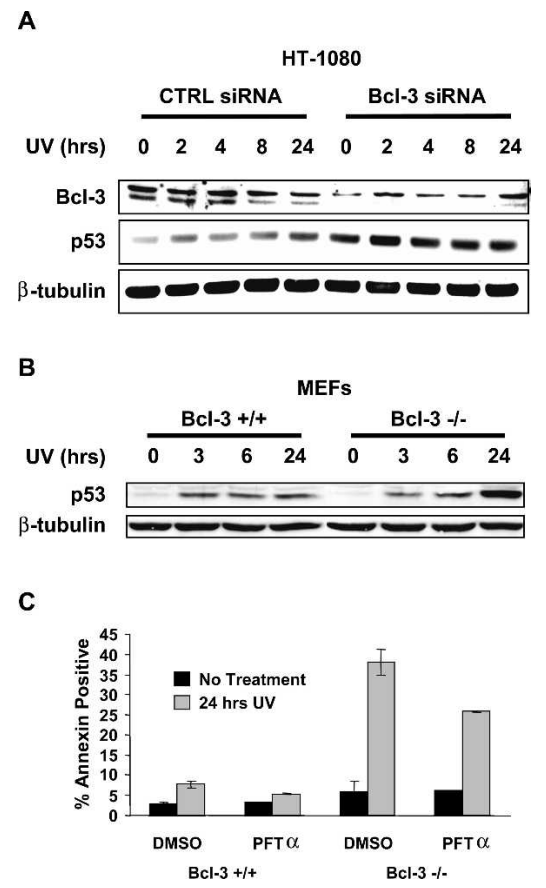

Figure 3. Loss of Bcl-3 leads to increased levels of p53 following DNA damage and sensitivity to DNA damage-induced apoptosis. (A) Knockdown of Bcl-3 results in an increase of UVinduced $\mathrm{p} 53$ protein. HT-1080 cells were transfected with a control siRNA or an siRNA targeting Bcl-3. Forty-eight hours after transfection, cells were treated with $40 \mathrm{~J} / \mathrm{m}^{2} \mathrm{UV}-\mathrm{C}$ for the indicated time points. Western analysis was performed on wholecell extracts using antibodies against Bcl-3, p53, and $\beta$-tubulin. (B) Bcl-3-null MEFs have increased p53 levels following UV treatment. Wild-type and Bcl-3-deficient MEFs were treated with $40 \mathrm{~J} / \mathrm{m}^{2}$ UV-C for the indicated time points. Western analysis was performed on whole-cell extracts using antibodies against p53 and $\beta$-tubulin. (C) Bcl-3-null MEFs are sensitized to p53-dependent UV-induced apoptosis. Bcl-3 $3^{+/+}$and $\mathrm{Bcl}_{-} 3^{-/-}$ MEFs were treated with DMSO, $10 \mu \mathrm{M}$ pifithrin- $\alpha, 40 \mathrm{~J} / \mathrm{m}^{2}$ UV-C plus DMSO, or $40 \mathrm{~J} / \mathrm{m}^{2} \mathrm{UV}-\mathrm{C}$ plus $10 \mu \mathrm{M}$ pifithrin- $\alpha$ as indicated. Eighteen hours after treatment, apoptosis was measured by flow cytometric analysis of Annexin-V staining.

\section{Bcl-3 expression leads to an increase in Hdm2 levels}

p53 activation is controlled through modifications (such as phosphorylation) and through interactions with its inhibitor Hdm2 (Vousden and Prives 2005). Analysis of UV-induced phosphorylation of p53 (Ser 15 and Ser 20) in MCF-7B cells indicated that this modification tracked with proteins levels (D. Kashatus, unpubl.), suggesting that Bcl-3 expression does not block p53 Ser 15 or Ser 20 phosphorylation. To analyze how high levels of expression of Bcl-3 might lead to the loss of p53 induction by DNA damage, we investigated the levels of the p53 inhibitor Hdm2. Western analysis of MCF-7 and MCF-7B cells reveals that MCF-7B cells exhibit consistently higher Hdm2 levels (Fig. 4A, first panel), providing a potential mechanism for the inhibition of p53 seen in these cells. Importantly, transient overexpression of Bcl-3 in parental MCF-7 cells also leads to increased Hdm2 protein (Fig. 4A, second panel), confirming that the increase 
A
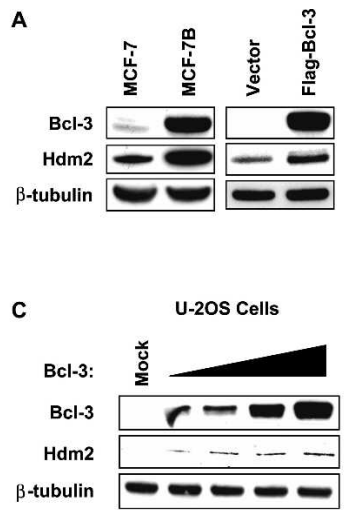

B
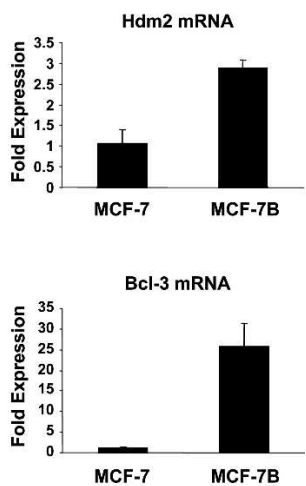

D
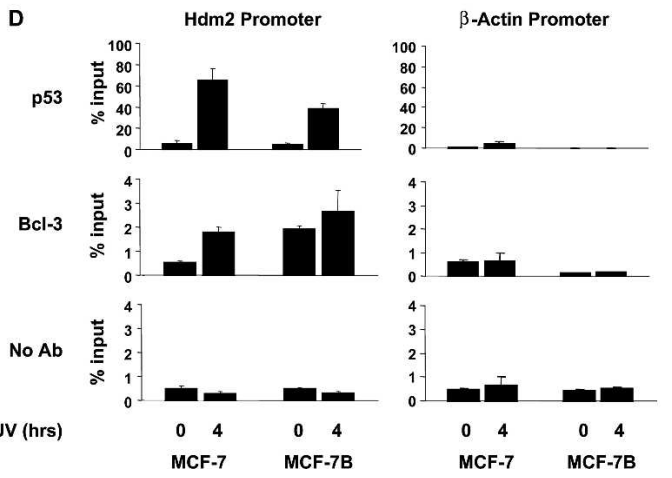

Figure 4. Overexpression of Bcl-3 leads to an increase in $\mathrm{Hdm} 2$ expression. $(A)$ Both transient and stable overexpression of Bcl-3 lead to higher basal levels of $\mathrm{Hdm} 2$ protein. Whole-cell extracts were prepared from MCF-7 and MCF-7B cells as well as MCF-7 cells transfected with $8 \mu \mathrm{g}$ of either empty vector or pCMVFlag-Bcl-3, and Western analysis was performed using antibodies against $\mathrm{Bcl}-3, \mathrm{Hdm} 2$, and $\beta$-tubulin. $(B)$ MCF-7B cells have higher basal levels of Hdm2 RNA. Real-time quantitative PCR was performed on CDNA prepared from MCF-7 and MCF-7B cells using primers specific for Bcl-3 and Hdm2. (Lane 1) Expression levels were normalized to expression of glucuronidase- $\beta$, and values represent fold difference relative to MCF-7 for each gene tested. $(C)$ Transient overexpression of Bcl-3 leads to an increase in $\mathrm{Hdm} 2$ levels in U-2OS cells. U-2OS cells were transfected with 0-200 ng of pCMV-Flag-Bcl-3 in 50-ng increments. Total DNA content was brought to $200 \mathrm{ng}$ with pCMV-Flag vector. Forty-eight hours after transfection, Western analysis was performed on whole-cell extracts using antibodies against $\mathrm{Bcl}-3, \mathrm{Hdm} 2$, and $\beta$-tubulin. (D) Bcl-3 is present at the $\mathrm{Hdm} 2$ promoter at higher levels in MCF-7B cells. MCF-7 and MCF-7B cells were treated with $40 \mathrm{~J} / \mathrm{m}^{2} \mathrm{UV}-\mathrm{C}$ for either 0 or $4 \mathrm{~h}$, and ChIP was performed using antibodies specific for p53 or Bcl-3, or no antibody. Real-time quantitative PCR was performed on precipitated DNA using primers specific for the $\mathrm{p} 2$ promoter region of the Hdm2 gene and for the promoter region of the $\beta$-actin gene. Values are normalized against the input DNA and are represented as the percentage of input for each given sample. Each value represents the mean of three independent measurements of the precipitated DNA, and the error bars represent one standard deviation. The experiment was repeated three times with identical results.

seen in the stable cells is not an artifact of clonal selection. This increase in $\mathrm{Hdm} 2$ in MCF-7B cells is also evident at the RNA level, as real-time quantitative PCR indicates a roughly threefold increase in $\mathrm{Hdm} 2$ levels in MCF-7B cells relative to parental MCF-7 cells. To show that this effect is not unique to MCF-7 cells, we transiently transfected Bcl-3 into the U-2OS osteosarcoma line. Consistent with the results from MCF-7 cells, increasing levels of Bcl-3 leads to proportionately increased levels of $\mathrm{Hdm} 2$ protein in these cells (Fig. 4C).

To determine whether the Bcl-3-dependent increase in $\mathrm{Hdm} 2$ might be due to a direct role for Bcl-3 at the Hdm2 promoter, we performed chromatin immunoprecipitation (ChIP) analysis using PCR primers specific for the P2 promoter region of the Hdm2 promoter, flanking the two conserved p53-binding sites. As reported for other p53 inducible genes (Espinosa et al. 2003), there are relatively low levels of p53 at the promoter under basal conditions, with a severalfold increase following UV treatment (Fig. 4D). Notably, the levels of p53 at the promoter $4 \mathrm{~h}$ post-UV are lower in the MCF-7B cells when compared with the parental MCF-7 cells, consistent with the lower levels of stabilized p53 in these cells. Intriguingly, Bcl-3 is also present at the $\mathrm{Hdm} 2$ promoter at levels consistent with its expression in the cells. In MCF-7 cells, Bcl-3 is not detectable basally but increases as the protein levels increase, while in the MCF-7B cells it is present both basally and after UV treatment (Fig. 4D). As a control, it is shown that neither Bcl-3 nor p53 is present at significant levels at the $\beta$-actin promoter.

The observed recruitment of Bcl-3 to the Hdm2 promoter led us to investigate potential binding sites for Bcl-3 in the Hdm2 P2 promoter region. We identified a putative NF-кB-binding site 275 base pairs (bp) upstream of the exon 2 start site that is conserved in the mouse Mdm2 promoter (Supplementary Fig. 2A). Intriguingly, gel shift analysis using a ${ }^{32} \mathrm{P}$-labeled oligonucleotide probe specific for this site shows increased binding to the probe in the MCF-7B cells compared with the parental MCF-7 cells. Further analysis using antibodies specific for various NF- $\mathrm{B}$ subunits shows that the complex binding this site contains both p50 and p52, known binding partners of Bcl-3 (Supplementary Fig. 2B).

In addition, we performed reporter assays using $\mathrm{Hdm} 2$ P2 luciferase reporters containing various portions of the P2 promoter. The two reporters containing the region of the promoter that includes the NF- $\mathrm{B}$-binding site (Hdm2-Luc-01 and Hdm2-Luc-02) consistently exhibit increased activity in the MCF-7B cells compared with the parental MCF-7 cells. Conversely, the reporter construct that lacks the region containing the NF-кB site (Hdm2-Luc-03) exhibits no difference between the two cell types (Supplementary Fig. 2C). While we cannot rule out the existence of other important regulatory sites in this deleted region, these data are consistent with the importance of this binding site for Bcl-3-induced Hdm2 transcription. 
Kashatus et al.

\section{Bcl-3 is required for Hdm2 gene expression}

Given that Bcl-3 is recruited to the Hdm2 promoter following UV treatment (Fig. 4D), and that its elevated expression leads to increased levels of $\mathrm{Hdm} 2$, we sought to determine whether $\mathrm{Bcl}-3$ is required for $\mathrm{Hdm} 2$ expression. Knockdown of Bcl-3 by RNA interference (RNAi) in both MCF-7 and Karpas 299 cells leads to a near complete loss of Hdm2 expression, consistent with Bcl-3 being required for basal $\mathrm{Hdm} 2$ expression in these cells (Fig. 5A). Note that Karpas 299 cells are reported to express mutant p53 (Hubinger et al. 2001), suggesting a lack of involvement of p53 in control of Hdm2 gene expression in these cells. To further test our hypothesis, primary fibroblasts from mice lacking Bcl-3 and their wild-type littermates were analyzed following DNA damage. When wild-type or Bcl-3-null MEFs are treated with either UV or the DNA damage-inducing drug cisplatin, cells lacking Bcl-3 fail to induce mdm2 mRNA to the levels seen in wild-type cells (Fig. 5B). Consistent with this, the induction of $\mathrm{Mdm} 2$ protein levels is severely repressed in $\mathrm{Bcl}-3^{-/-}$cells as compared with their wild-type counterparts (Fig. 5C). To determine if suppression of Bcl-3 inhibits the induction of $\mathrm{Hdm} 2$ in another cell type, siRNA was utilized to suppress Bcl-3 expression in HT-1080 cells, which express functional p53 (Suzuki et al. 2003). Knockdown of Bcl-3 in HT-1080 cells also leads to a suppression of the induction of Hdm2 following UV treatment (Fig. 5D). These results demonstrate an important role for Bcl-3 in controlling $\mathrm{Hdm} 2 / \mathrm{mdm} 2$ gene expression in several cell types.
Disruption of the p53-Hdm2 interaction in MCF-7B cells rescues the DNA damage-induced p53 response

To determine if Bcl-3-mediated repression of DNA damage-induced p53 stability involves $\mathrm{Hdm} 2$, we analyzed whether disruption of the p53-Hdm 2 interaction is able to rescue p53 responsiveness in MCF-7B cells. The recently described compound RITA /reactivation of p53 and induction of tumor cell apoptosis) has been shown to bind to p53 both in vitro and in vivo and to prevent its interaction with Hdm2 (Issaeva et al. 2004). MCF-7 and MCF-7B (Bcl-3-expressing) cells were exposed to RITA or to diluent, and to UV treatment. The results demonstrate the expected p53 induction in MCF-7 cells and the strong suppression of p53 activation in MCF-7B cells. Importantly, exposure of the MCF-7B cells to RITA leads to a rescue of the Bcl-3-controlled repression of p53 as evidenced by higher levels of p53 stabilization than in cells treated with UV and vehicle control (Fig. 6A). To test the $\mathrm{Hdm} 2$ dependence in another way, we transfected MCF-7B cells with either a control siRNA or an siRNA specific for $\mathrm{Hdm} 2$. Consistent with the response following RITA treatment, knockdown of $\mathrm{Hdm} 2$ in MCF-7B cells leads to a rescue of the p53 response following UV treatment (Fig. 6B). Collectively, these data indicate that the repression of p53 induction seen in MCF-7B cells is dependent on the p53-Hdm2 interaction, consistent with the model that increased $\mathrm{Hdm} 2$ levels in MCF-7B cells are responsible for the repression.

To determine if the protection against apoptosis observed in MCF-7B cells (Fig. 1) is dependent on Hdm2mediated repression of p53, MCF-7 and MCF-7B cells
Figure 5. Loss of Bcl-3 leads to a decrease in basal and DNA damage-inducible Hdm2 expression. (A) Knockdown of Bcl-3 in human cancer cells leads to loss of Hdm2 expression. MCF-7 and Karpas 299 cells were transfected with either control siRNAs or siRNAs specific for Bcl-3. Forty-eight hours after transfection, Western analysis was performed on whole-cell extracts using antibodies specific for Bcl-3, Hdm2, and $\beta$-tubulin. (B) DNA damage fails to induce Mdm2 RNA in Bcl-3-deficient fibroblasts. Wild-type and Bcl-3-null MEFs were treated with either $40 \mathrm{~J} / \mathrm{m}^{2} \mathrm{UV}-\mathrm{C}$ or $10 \mu \mathrm{g} / \mathrm{mL}$ cisplatin for the indicated times, and $\mathrm{Mdm} 2$ gene expression was measured by quantitative real-time PCR. (Lane 1) Expression levels were normalized to expression of GAPDH, and the values represent the fold increase or decrease relative to untreated wild-type MEFs. (C) DNA damage fails to induce Mdm2 protein in Bcl-3-deficient fibroblasts. Wild-type and Bcl-3-null MEFs were treated with $40 \mathrm{~J} / \mathrm{m}^{2} \mathrm{UV}-\mathrm{C}$ for the indicated times, and Western blots were performed on whole-cell extracts using antibodies specific for $\mathrm{Mdm} 2$ and $\beta$-tubulin. $(D)$ Knockdown of Bcl-3 impairs the ability of DNA damage to induce Hdm2 in HT-1080 cells. HT-1080 cells were transfected with either control siRNAs or siRNAs specific for Bcl-3. Forty-eight hours after transfection, cells were treated with $40 \mathrm{~J} / \mathrm{m}^{2} \mathrm{UV}-\mathrm{C}$ for the indicated times, and Western analysis was performed on whole-cell extracts using antibodies specific for Bcl-3, $\mathrm{Hdm} 2$, and $\beta$-tubulin.

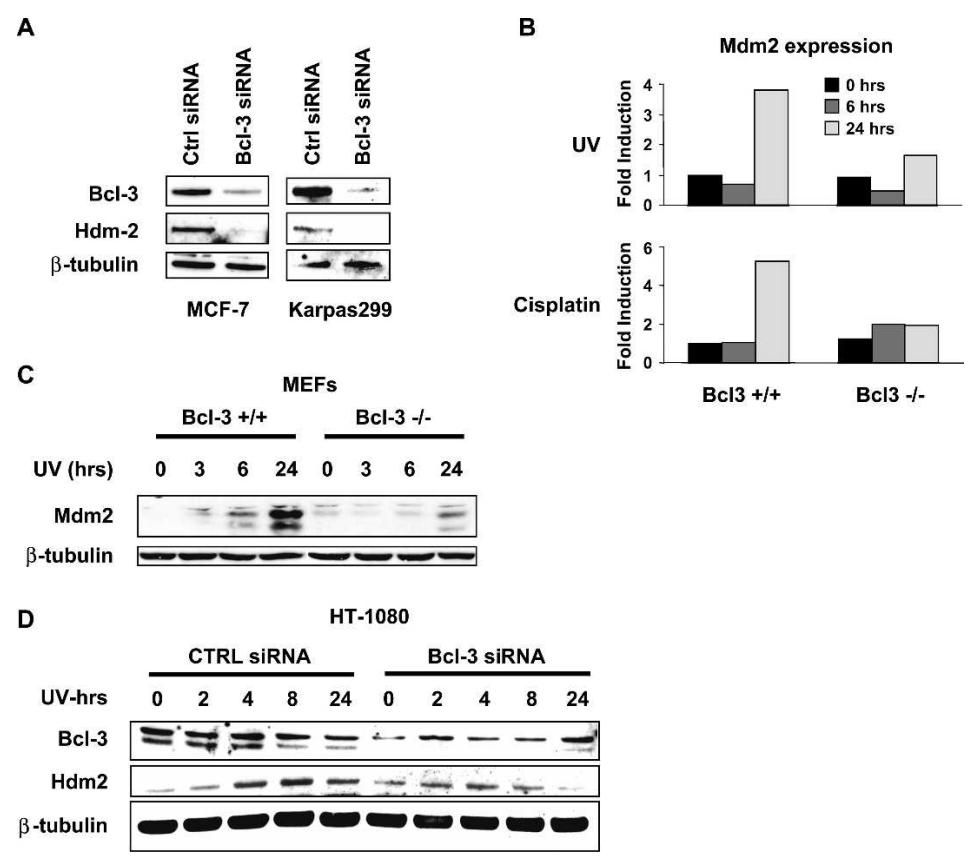


A

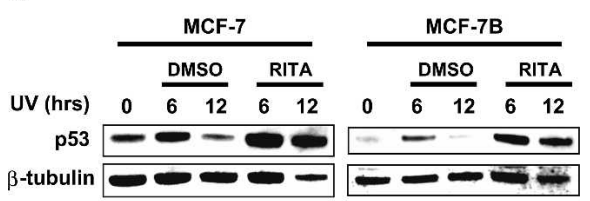

B

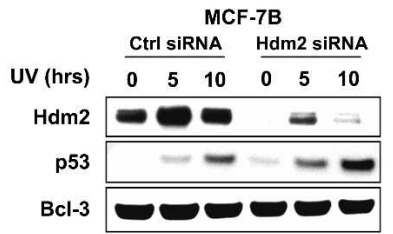

C

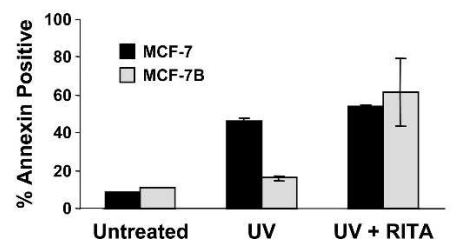

Figure 6. Disruption of the $\mathrm{p} 53-\mathrm{Hdm} 2$ interaction rescues the effects of Bcl-3 overexpression. (A) Disruption of the p53-Hdm2 interaction restores the ability of UV to induce p53 in MCF-7B cells. MCF-7 and MCF-7B cells were pretreated for $30 \mathrm{~min}$ with either DMSO or $2 \mu \mathrm{M}$ RITA and then treated with $40 \mathrm{~J} / \mathrm{m}^{2}$ UV-C for the indicated times. Whole-cell extracts were prepared and subjected to Western blot analysis using antibodies specific for $\mathrm{p} 53$ and $\beta$-tubulin. (B) Knockdown of $\mathrm{Hdm} 2$ restores the ability of UV to induce p53 in MCF-7B cells. MCF-7B cells were transfected with either a control siRNA or an siRNA specific for Hdm2. Forty-eight hours after transfection, cells were treated with $40 \mathrm{~J} / \mathrm{m}^{2} \mathrm{UV}-\mathrm{C}$ for the indicated times. Whole-cell extracts were prepared and subjected to Western blot analysis using antibodies specific for p53, $\mathrm{Hdm} 2$, and $\beta$-tubulin. (C) Disruption of the p53-Hdm2 interaction restores the ability of UV to induce apoptosis in MCF-7B cells. MCF-7 and MCF-7B cells were left untreated, or were treated with $40 \mathrm{~J} / \mathrm{m}^{2} \mathrm{UV}-\mathrm{C}$ or with $40 \mathrm{~J} / \mathrm{m}^{2}$ UV-C plus $2 \mu \mathrm{M}$ RITA. Eighteen hours after treatment, apoptosis was measured by flow cytometric analysis of Annexin-V staining.

were either treated with UV alone or with UV plus RITA and the apoptotic response was measured. Consistent with the data from Figure 1, MCF-7B cells are significantly protected against apoptosis when treated with UV alone. However, cotreatment with RITA rescues the apoptotic defect in MCF-7B cells. Importantly, cotreatment with UV and RITA results in equivalent levels of apoptosis in MCF-7 and MCF-7B cells, demonstrating that the interaction between p53 and Hdm 2 is critical for the observed apoptotic differences in the two cell lines (Fig. 6C). Similarly, siRNA-mediated knockdown of $\mathrm{Hdm} 2$ is able to restore the UV-induced apoptotic response in MCF-7B cells (Supplementary Fig. 3), albeit to a lesser extent than treatment with RITA. This is likely due to a $<100 \%$ transfection efficiency in these cells leading to an incomplete knockdown of $\mathrm{Hdm} 2$. These data further demonstrate the importance of the p53-
Hdm2 interaction on the antiapoptotic effects of Bcl-3. Collectively, these data indicate that the Bcl-3-mediated protection against DNA damage-induced apoptosis involves the regulated interaction between p53 and $\mathrm{Hdm} 2$ and supports the hypothesis that Bcl-3-controlled induction of $\mathrm{Hdm} 2$ is responsible for the observed repression of $\mathrm{p} 53$.

\section{Discussion}

The data presented here reveal a surprising pro-oncogenic role for the oncoprotein Bcl-3, namely, its ability to suppress the activation of the p53 tumor suppressor protein in response to DNA damage. A major proposed mechanism in this regulatory circuit is the ability of Bcl-3 to induce the expression of $\mathrm{Hdm} 2$, the inhibitor of p53. The experiments demonstrate that expression of Bcl-3 leads to an increase in Hdm2 levels and to a subsequent loss of DNA damage-induced p53 protein stability. The consequence of the Bcl-3-mediated inhibition of p53 is a loss of induction of p53 target genes and protection against DNA damage-induced apoptosis. Interestingly, the loss of Bcl-3 leads to the inability of p53 to induce hdm2 transcription and, correspondingly, to enhanced p53 protein stability, suggesting that a normal physiological role of $\mathrm{Bcl}-3$ is to limit the p53 activation response.

Bcl-3 overexpression is characteristic of a growing number of human cancers (Cogswell et al. 2000; Thornburg et al. 2003; Canoz et al. 2004), yet a specific oncogenic role for Bcl-3 in these cancers has been elusive. Recently we and others (Westerheide et al. 2001; Rocha et al. 2003) demonstrated that Bcl-3 can contribute to cyclin D1 transcription, a key component in driving cell cycle progression. The finding that Bcl-3 can inhibit p53 function provides a novel mechanism for how aberrant Bcl-3 expression can fulfill an oncogenic function. The importance of p53 as a tumor suppressor is illustrated by the fact that it is mutated or lost in over half of all human cancers tested (Vousden and Lu 2002; Vousden and Prives 2005), and presumably cancer cells with wild-type p53 have compromised its function through different mechanisms. Loss of the tumor suppressor ARF and high level expression of $\mathrm{Hdm} 2$ have been thought to be two of main ways that this is achieved. Consistent with this, it has been reported (Bond et al. 2004) that an Hdm2 promoter polymorphism increases affinity for the transcription factor Sp1 promoting high level transcription and subsequent attenuation of the p53 response. In addition, N-Myc (Slack et al. 2005) and estrogen receptor- $\alpha$ (Phelps et al. 2003) can regulate $\mathrm{Hdm} 2$ in a p53-independent fashion. Similarly, Bcl-3, through induction of $\mathrm{Hdm} 2$, would provide a level of inhibition to p53 that tumor cells need to progress, bypassing the need for mutation or deletion of p53.

Current models of p53 activation by DNA damage suggest that post-translational modification of $\mathrm{p} 53$ disrupts its interaction with $\mathrm{Hdm} 2$, and thus it might be suggested that any increase in Hdm2 protein levels would have a minimal effect on p53 protein stability following 
DNA damage. However, it is likely that the dynamics of the DNA damage response are more complex. First, it has been reported that modification of both p53 and $\mathrm{Hdm} 2$ is important for the disruption of the interaction (L.D. Mayo et al. 1997; Hay and Meek 2000), suggesting that a consistent supply of newly transcribed Hdm2 induced by Bcl-3 would provide a steady stream of unmodified Hdm2 to re-engage p53. Further, the fact that p53induced $\mathrm{Hdm} 2$ provides negative feedback regulation of p53 suggests that at some point following the initial damage event, the newly transcribed Hdm2 is able to rebind to p53 and turn off the response. Consistent with this, our data indicate that Bcl-3-induced $\mathrm{Hdm} 2$ will indeed have the effect of dampening the p53 response. This conclusion is further supported by the many reports of $\mathrm{Hdm} 2$ overexpression in human cancers (Momand et al. 1998).

Furthermore, while our data indicate that Bcl-3 can regulate p53 through induction of $\mathrm{Hdm} 2$, we cannot rule out additional roles for Bcl-3 in regulating p53 function. For example, certain p53-dependent genes have NF-кB consensus sites in their promoters, and Bcl-3, presumably through interactions with the p50 or p52 NF-кB subunits, may play a direct role in the regulation of those genes. In fact, we have found recruitment of Bcl-3 as well as other NF- $\mathrm{kB}$ subunits to a number of those promoters and are currently investigating those mechanisms (D. Kashatus, unpubl.). In addition, higher levels of Bcl-3 may affect NF-кB dimer composition and indirectly affect NF- $\mathrm{B}$ regulation of those promoters. It is also possible that Bcl-3 regulates p53 protein levels or functional activity through additional mechanisms. While we find no evidence that Bcl-3 has a role in direct transcriptional regulation of p53, it may affect p53 through control of stability or translational efficacy.

The finding of this novel function for Bcl-3 raises intriguing questions regarding a role for Bcl-3 in development, immune and inflammatory function, and the stress response. An indication of what that role may be comes from a the recent finding that Bcl-6, a transcriptional repressor also found aberrantly expressed in B-cell lymphomas that is unrelated to Bcl-3, directly inhibits p53 transcription in germinal center B cells (Phan and Dalla-Favera 2004). This negative regulation of p53 is presumed to be important to allow these cells to tolerate the DNA damage required for immunoglobulin class switch recombination and somatic hypermutation without mounting an apoptotic response. Our new data, plus the fact that Bcl-3 knockout mice, like the Bcl-6 knockouts, fail to properly develop germinal centers (Franzoso et al. 1997), suggest that Bcl-3 may function to block p53 activation in germinal center $B$ cells, but through a different mechanism than that reported for Bcl-6. It has also been shown that expression of Bcl-3 correlates with survival in adjuvant-induced $\mathrm{T}$ cells (Mitchell et al. 2001). Activated $\mathrm{T}$ cells require a survival signal following antigen stimulation in order to avoid apoptosis and to undergo clonal expansion. The apoptotic signal has been shown to be mediated by the p53 family member p73 (Wan and DeGregori 2003). Given its role in p53 inhibi- tion, Bcl-3 may protect activated T cells through downregulation of this apoptotic response by inhibiting p73 through a similar mechanism. The failure of Bcl-3-null mice to mount an effective $\mathrm{T}$-cell response to influenza virus supports this role for Bcl-3 (Franzoso et al. 1997). Finally, we observe that Bcl-3 is activated by UV, potentially at the level of protein stabilization (Fig. 2). Given that loss of Bcl-3 leads to enhanced p53 activation and to enhanced apoptosis (Fig. 3), it is likely that the induction of Bcl-3 by UV (or by other DNA damaging agents) functions normally to limit p53 induction and apoptosis.

Given the previous intriguing results regarding both cooperative (Ryan et al. 2000) and antagonistic (Webster and Perkins 1999) relationships between the NF-кB and p53 pathways, it would be expected that the findings reported here relate to these original findings. However, the direct relationship between Bcl-3 expression and the classic NF- $\mathrm{B}$ pathway remains unclear. In this regard, it has been reported that Bcl-3 gene expression can be induced in an NF-кB-dependent manner (Brasier et al. 2001). Our analyses of p65 null MEFs, however, do not reveal a similar defect in $\mathrm{mdm} 2$ expression or p53 stabilization (D. Kashatus, unpubl.), suggesting the Bcl-3-mediated regulation is p65 independent. Further analysis of cells lacking other NF-кB subunits, specifically p50 and p52, should allow us to determine their requirement in this regulation. The fact that loss of IKK $\beta$ leads to a loss of $\mathrm{mdm} 2$ induction suggests that this kinase may function upstream of Bcl-3 in this response (Tergaonkar et al. 2002). IKK $\beta$ may act through regulation of p50 or p52, or it could potentially be involved in the DNA damageinduced stabilization of Bcl-3 through direct phosphorylation.

In summary, our findings provide a critical understanding of the functional consequences of Bcl-3 expression in human cancer cells and could potentially have direct clinical applications for cancer treatment. Unlike Bcl-3, p53 and Hdm2 are popular targets for drug development, and these findings may provide rationale for a potential new intervention pathway for certain cancers. These data also provide an additional link in the expanding relationships between the NF-кB/IкB family and p53, and open new avenues for exploration into how these two important protein families interact to control oncogenesis.

\section{Materials and methods}

\section{Cell culture}

Primary murine embryo fibroblasts were isolated from day 13 embryos and grown in DMEM supplemented with $10 \%$ fetal bovine serum (FBS) (Sigma) and $1 \times$ penicillin/streptomycin (GIBCO). MCF-7 cells (ATCC) were grown in MEM $\alpha$ supplemented with $10 \%$ FBS, $10 \mu \mathrm{g} / \mathrm{mL}$ insulin (GIBCO), $1 \mathrm{mM}$ sodium pyruvate $(\mathrm{GIBCO})$, and $1 \times$ penicillin/streptomycin. Karpas 299 cells (DSMZ) were grown in RPMI supplemented with $10 \%$ FBS and $1 \times$ penicillin/streptomycin. HT1080 cells (ATCC) were grown in DMEM supplemented with $10 \%$ FBS and $1 \times$ penicillin/streptomycin. U-2OS cells (ATCC) were grown in McCoys 
5A supplemented with $15 \%$ FBS and $1 \times$ penicillin/streptomycin. MCF-7B cells were generated by transfecting the expression construct pFlag-Bcl-3 into MCF-7 cells. Stable clones were generated in medium containing $1 \mu \mathrm{g} / \mathrm{mL}$ puromycin (Sigma). Clones were verified by Western blotting with a Bcl-3-specific antibody. Cisplatin (Sigma) was resuspended in DMSO and stored at $-20^{\circ} \mathrm{C}$. RITA was resuspended in DMSO to a concentration of $10 \mathrm{mM}$ and stored in the dark at $-20^{\circ} \mathrm{C}$. Pifithrin- $\alpha$ (A.G. Scientific) was resuspended in DMSO to a concentration of $10 \mathrm{mM}$ and stored in the dark at $-20^{\circ} \mathrm{C}$. Staurosporine (Sigma) was resuspended in DMSO to a concentration of $2 \mathrm{mM}$ and stored at $-20^{\circ} \mathrm{C}$. For UV treatments, cells were placed under a UV lamp and dosage was measured with a UV-X radiometer (Ultra Violet Products).

\section{Antibodies}

For Western blots, ChIP analysis, and supershift analysis, we used antibodies against p53 (FL393, Santa Cruz), Bcl-3 (Upstate), $\mathrm{Hdm} 2$ (Ab-1, Calbiochem), mdm2 (2A10, from A. Levine, Institute for Advanced Study, Princeton, NJ), Flag (M2, Sigma), p65 (5192, Rockland), p52 (from N. Rice, National Cancer Institute, Frederick, MD), p50 (H-119, Santa Cruz), and $\beta$-tubulin (H-235, Santa Cruz). HRP-conjugated anti-mouse and anti-rabbit IgG secondary antibodies were from Promega.

\section{Western blot}

Typically, cells were plated in a $100-\mathrm{mm}$ or 6-well tissue culture dish and treated as indicated. After the indicated time points, cells were wash with PBS and lysed in modified RIPA buffer $(1 \%$ NP40, 20 mM Tris, $137 \mathrm{mM} \mathrm{NaCl}, 10 \%$ glycerol, 2 mM EDTA, $2 \mu \mathrm{g} / \mathrm{mL}$ aprotinin, $2 \mu \mathrm{g} / \mathrm{mL}$ leupeptin, $1 \mathrm{mM}$ PMSF); 10 or $15 \mu \mathrm{g}$ of protein was loaded onto $4 \%-12 \%$ Bis-Tris gels (Invitrogen). After electrophoresis, gels were transferred to nitrocellulose (Bio-Rad) and blocked for $1 \mathrm{~h}$ in TBS containing 0.5\% Tween-20, $4 \%$ milk, and $1 \%$ BSA. Primary and secondary antibody incubations were performed in blocking buffer at $4^{\circ} \mathrm{C}$ (primary) or room temperature (secondary).

\section{Apoptosis detection}

Cells were plated in 100-mm dishes and treated with the indicated dose of UV or cisplatin. At the indicated time points, cells were washed with PBS and collected by trypsinization. Cells were washed again in PBS and resuspended in $100 \mu \mathrm{L}$ annexinbinding buffer (10 mM HEPES, $140 \mathrm{mM} \mathrm{NaCl}, 2.5 \mathrm{mM} \mathrm{CaCl}_{2}$ at $\mathrm{pH}$ 7.4) containing $5 \mu \mathrm{L}$ Alexa-488 conjugated Annexin-V (Molecular Probes) plus $1 \mu \mathrm{g} / \mathrm{mL}$ propidium iodide (Sigma). Cells were incubated for $15 \mathrm{~min}$ at room temperature and then analyzed on a Facscalibur (Becton Dickinson). Apoptotic cells were measured as positive for Annexin- $\mathrm{V}$ staining but negative for propidium iodide.

\section{Plasmid constructs}

pCMV2-Flag-Bcl-3 (Westerheide et al. 2001), pCMV-Flag-p53 (Zhang et al. 1998), pg-13-luciferase (el-Deiry et al. 1993), and Hdm2-Luc01, Hdm2-Luc02, and Hdm2-Luc03 (Phelps et al. 2003) were described previously.

\section{ChIP assay}

ChIP analysis was performed using a ChIP kit (Upstate Biotechnology) and a modified version of the manufacturer's protocol. Following the indicated treatment, cells were fixed for $5 \mathrm{~min}$ in $1 \%$ formaldehyde, washed with PBS, and lysed for $10 \mathrm{~min}$ in lysis buffer. Chromatin was sheared by sonication to an average size of $\sim 1 \mathrm{~kb}$ and precleared for $2 \mathrm{~h}$ at $4^{\circ} \mathrm{C}$ with salmon sperm DNA-saturated protein G-Sepharose beads. Chromatin solutions were precipitated overnight at $4^{\circ} \mathrm{C}$ using $10 \mu \mathrm{L}$ of the indicated antibodies. Immune complexes were collected with salmon sperm DNA-saturated protein G-Sepharose beads for $1 \mathrm{~h}$ and washed extensively following the manufacturer's protocol. Input and immunoprecipitated chromatin were incubated overnight at $65^{\circ} \mathrm{C}$ to reverse cross-links. After proteinase $\mathrm{K}$ digestion, DNA was extracted with phenol/chloroform and precipitated with ethanol. Precipitated DNAs were analyzed by realtime PCR on an ABI 7100 using SYBR green master mix (ABI). Each sample was normalized to input using the $2^{-\Delta \Delta C(T)}$ method (Livak and Schmittgen 2001). Hdm2 P2 promoter-specific primers used were $5^{\prime}$-GAGGTCCGGATGATCGCAGG-3' and 5'GTGGCGTGCGTCCGTGCCCA-3', and $\beta$-actin promoterspecific primers used were 5'-CСТССТССТTCTTCСТCA ATCT-3' and 5'-GGGGAGAGGGGAGGAAA-3'.

\section{Luciferase assays}

Typically, cells were plated in 24-well dishes and allowed to grow to $\sim 70 \%$ confluency. Cells were transfected with the indicated plasmids using polyfect reagent (Qiagen) following the manufacturer's protocol. Forty-eight hours post-transfection, extracts were prepared using the Dual Luciferase Assay System (Promega) following the manufacturer's protocol, and luciferase activity was measured on an LMax luminometer (Molecular Devices).

\section{Real-time PCR}

Cells were plated in $100-\mathrm{mm}$ dishes and treated with the indicated doses of UV or cisplatin. At the indicated time points, cells were washed in PBS and lysed in Trizol Reagent (Invitrogen), and RNA was collected following the manufacturer's protocol. cDNA was generated using the M-MLV reverse transcriptase kit (Invitrogen), and quantitative PCR was performed on an ABI Prism 7000 (Applied Biosystems) using gene-specific TAQman primer/probe sets (Applied Biosystems).

\section{RNAi}

Synthetic double-stranded RNA (dsRNA) oligonucleotides targeting Bcl-3 and Hdm2 were purchased from Xeragon and Ambion, respectively. The targeted sequence for Bcl-3 is $5^{\prime}$-AATG GTCTTCTCTCCGCATCA-3'. Cells were plated in six-well dishes and allowed to grow to $\sim 70 \%$ confluency. Transfection of the gene specific siRNA plus a control siRNA (Ambion) was performed using the transmessenger transfection reagent (Ambion) according to the manufacturer's protocol. Forty-eight hours post-transfection, cells were treated for the indicated time points and lysed, and Western analysis was performed as described.

\section{Electrophoretic mobility shift assay (EMSA)}

Nuclear and cytoplasmic extracts were obtained from MCF-7 and MCF-7B cells, and gel shift analysis was performed as previously described (M.W. Mayo et al. 1997). Briefly, an oligonucleotide corresponding to the putative NF-кB site in the Hdm2 P2 promoter (5'-GGTGGTTCGGAGGTCTCCGCGG GAGT-3') was radiolabeled using $\left[\alpha{ }^{32}\right.$ P]dCTP (Perkin Elmer). The probe was incubated with $4 \mu \mathrm{g}$ of nuclear extract and $0.1 \mu \mathrm{g} /$ $\mu \mathrm{L}$ poly dIdC in DNA-binding buffer $(50 \mathrm{mM} \mathrm{NaCl}, 10 \mathrm{mM}$ Tris at $\mathrm{pH}$ 7.6, $10 \%$ glycerol, $1 \mathrm{mM} \mathrm{DTT}, 0.5 \mathrm{mM}$ EDTA) for $15 \mathrm{~min}$ 
at room temperature. For antibody supershift analysis, extracts were preincubated for $15 \mathrm{~min}$ at room temperature with $1 \mu \mathrm{g}$ of antiserum before the addition of the radiolabeled gel shift probe. Reactions were separated using nondenaturing PAGE and visualized by autoradiography.

\section{Acknowledgments}

We thank Dr. Arnold Levine for providing the $\mathrm{mdm} 2$ antibody, Dr. Galina Selivanova for providing the RITA compound, Dr. Jeremy Blaydes for providing the Hdm2 promoter luciferase constructs, Dr. Nancy Rice for providing the p52 antibody, Dr. Yue Xiong for providing the pCMV-p53 construct, Dr. Ned Sharpless for providing the pg-13 luciferase construct and for helpful discussions, and Dr. Kris Steinbrecher for help generating MEFs. Research support was provided by NIH grants AI35098, CA73756, and CA75080 to A.S.B; by the Department of Defense (DAMD 17-03-1-0401) to A.S.B.; and by the UNC Breast Cancer SPORE program. Additional support was provided by the Waxman Cancer Research Foundation. The authors have no conflict of interest relative to the data reported in this manuscript.

\section{References}

Barak, Y., Juven, T., Haffner, R., and Oren, M. 1993. mdm2 expression is induced by wild type p53 activity. EMBO $\mathrm{J}$. 12: 461-468.

Bond, G.L., Hu, W., Bond, E.E., Robins, H., Lutzker, S.G., Arva, N.C., Bargonetti, J., Bartel, F., Taubert, H., Wuerl, P., et al. 2004. A single nucleotide polymorphism in the MDM2 promoter attenuates the p53 tumor suppressor pathway and accelerates tumor formation in humans. Cell 119: 591-602.

Bond, G.L., Hu, W., and Levine, A.J. 2005. MDM2 is a central node in the p53 pathway: 12 years and counting. Curr. Cancer Drug Targets 5: 3-8.

Boulton, S.J., Gartner, A., Reboul, J., Vaglio, P., Dyson, N., Hill, D.E., and Vidal, M. 2002. Combined functional genomic maps of the C. elegans DNA damage response. Science 295: $127-131$.

Bours, V., Franzoso, G., Azarenko, V., Park, S., Kanno, T., Brown, K., and Siebenlist, U. 1993. The oncoprotein Bcl-3 directly transactivates through $\kappa \mathrm{B}$ motifs via association with DNA-binding p50B homodimers. Cell 72: 729-739.

Brasier, A.R., Lu, M., Hai, T., Lu, Y., and Boldogh, I. 2001. NF-к B-inducible BCL-3 expression is an autoregulatory loop controlling nuclear p50/NF-к B1 residence. J. Biol. Chem. 276: 32080-32093.

Canoz, O., Rassidakis, G.Z., Admirand, J.H., and Medeiros, L.J. 2004. Immunohistochemical detection of BCL-3 in lymphoid neoplasms: A survey of 353 cases. Mod. Pathol. 17: 911-917.

Chipuk, J.E., Kuwana, T., Bouchier-Hayes, L., Droin, N.M., Newmeyer, D.D., Schuler, M., and Green, D.R. 2004. Direct activation of Bax by p53 mediates mitochondrial membrane permeabilization and apoptosis. Science 303: 1010-1014.

Cogswell, P.C., Guttridge, D.C., Funkhouser, W.K., and Baldwin Jr., A.S. 2000. Selective activation of NF-к B subunits in human breast cancer: Potential roles for NF-к B2/p52 and for Bcl-3. Oncogene 19: 1123-1131.

Dechend, R., Hirano, F., Lehmann, K., Heissmeyer, V., Ansieau, S., Wulczyn, F.G., Scheidereit, C., and Leutz, A. 1999. The $\mathrm{Bcl}-3$ oncoprotein acts as a bridging factor between NF-kB/ Rel and nuclear co-regulators. Oncogene 18: 3316-3323.
el-Deiry, W.S., Tokino, T., Velculescu, V.E., Levy, D.B., Parsons, R., Trent, J.M., Lin, D., Mercer, W.E., Kinzler, K.W., and Vogelstein, B. 1993. WAF1, a potential mediator of p53 tumor suppression. Cell 75: 817-825.

Espinosa, J.M., Verdun, R.E., and Emerson, B.M. 2003. p53 functions through stress- and promoter-specific recruitment of transcription initiation components before and after DNA damage. Mol. Cell 12: 1015-1027.

Franzoso, G., Carlson, L., Scharton-Kersten, T., Shores, E.W., Epstein, S., Grinberg, A., Tran, T., Shacter, E., Leonardi, A., Anver, M., et al. 1997. Critical roles for the Bcl-3 oncoprotein in $\mathrm{T}$ cell-mediated immunity, splenic microarchitecture, and germinal center reactions. Immunity 6: 479-490.

Ghosh, S. and Karin, M. 2002. Missing pieces in the NF-кB puzzle. Cell 109(Suppl): S81-S96.

Hay, T.J. and Meek, D.W. 2000. Multiple sites of in vivo phosphorylation in the MDM2 oncoprotein cluster within two important functional domains. FEBS Lett. 478: 183-186.

Hayden, M.S. and Ghosh, S. 2004. Signaling to NF-кB. Genes \& Dev. 18: 2195-2224.

Hubinger, G., Muller, E., Scheffrahn, I., Schneider, C., Hildt, E., Singer, B.B., Sigg, I., Graf, J., and Bergmann, L. 2001. CD30mediated cell cycle arrest associated with induced expression of $\mathrm{p} 21$ (CIP1/WAF1) in the anaplastic large cell lymphoma cell line Karpas 299. Oncogene 20: 590-598.

Issaeva, N., Bozko, P., Enge, M., Protopopova, M., Verhoef, L.G., Masucci, M., Pramanik, A., and Selivanova, G. 2004. Small molecule RITA binds to p53, blocks p53-HDM-2 interaction and activates p53 function in tumors. Nat. Med. 10: 13211328.

Jeffers, J.R., Parganas, E., Lee, Y., Yang, C., Wang, J., Brennan, J., MacLean, K.H., Han, J., Chittenden, T., Ihle, J.N., et al. 2003. Puma is an essential mediator of p53-dependent and -independent apoptotic pathways. Cancer Cell 4: 321-328.

Komarov, P.G., Komarova, E.A., Kondratov, R.V., ChristovTselkov, K., Coon, J.S., Chernov, M.V., and Gudkov, A.V. 1999. A chemical inhibitor of p53 that protects mice from the side effects of cancer therapy. Science 285: 1733-1737.

Kucharczak, J., Simmons, M.J., Fan, Y., and Gelinas, C. 2003. To be, or not to be: NF-кB is the answer: Role of Rel/NF-кB in the regulation of apoptosis. Oncogene 22: 8961-8982.

Livak, K.J. and Schmittgen, T.D. 2001. Analysis of relative gene expression data using real-time quantitative PCR and the $2^{-\Delta \Delta(\mathrm{T})}$ method. Methods 25: 402-408.

Mayo, L.D., Turchi, J.J., and Berberich, S.J. 1997. Mdm-2 phosphorylation by DNA-dependent protein kinase prevents interaction with p53. Cancer Res. 57: 5013-5016.

Mayo, M.W., Wang, C.Y., Cogswell, P.C., Rogers-Graham, K.S., Lowe, S.W., Der, C.J., and Baldwin Jr., A.S. 1997. Requirement of NF- $\kappa$ B activation to suppress p53-independent apoptosis induced by oncogenic Ras. Science 278: 1812-1815.

McKeithan, T.W., Rowley, J.D., Shows, T.B., and Diaz, M.O. 1987. Cloning of the chromosome translocation breakpoint junction of the $t(14 ; 19)$ in chronic lymphocytic leukemia. Proc. Nat1. Acad. Sci. 84: 9257-9260.

Mitchell, T.C., Hildeman, D., Kedl, R.M., Teague, T.K., Schaefer, B.C., White, J., Zhu, Y., Kappler, J., and Marrack, P. 2001. Immunological adjuvants promote activated $\mathrm{T}$ cell survival via induction of Bcl-3. Nat. Immunol. 2: 397-402.

Momand, J., Jung, D., Wilczynski, S., and Niland, J. 1998. The MDM2 gene amplification database. Nucleic Acids Res. 26: 3453-3459.

Na, S.Y., Choi, H.S., Kim, J.W., Na, D.S., and Lee, J.W. 1998. $\mathrm{Bcl} 3$, an IкB protein, as a novel transcription coactivator of the retinoid X receptor. J. Biol. Chem. 273: 30933-30938.

Nakano, K. and Vousden, K.H. 2001. PUMA, a novel proapo- 
ptotic gene, is induced by p53. Mol. Cell 7: 683-694.

Nishikori, M., Maesako, Y., Ueda, C., Kurata, M., Uchiyama, T., and Ohno, H. 2003. High-level expression of BCL3 differentiates $\mathrm{t}(2 ; 5)(\mathrm{p} 23 ; \mathrm{q} 35)$-positive anaplastic large cell lymphoma from Hodgkin disease. Blood 101: 2789-2796.

Nolan, G.P., Fujita, T., Bhatia, K., Huppi, C., Liou, H.C., Scott, M.L., and Baltimore, D. 1993. The bcl-3 proto-oncogene encodes a nuclear I $\kappa$ B-like molecule that preferentially interacts with NF-к B p50 and p52 in a phosphorylation-dependent manner. Mol. Cell. Biol. 13: 3557-3566.

Oda, E., Ohki, R., Murasawa, H., Nemoto, J., Shibue, T., Yamashita, T., Tokino, T., Taniguchi, T., and Tanaka, N. 2000. Noxa, a BH3-only member of the Bcl-2 family and candidate mediator of p53-induced apoptosis. Science 288: 1053-1058.

Phan, R.T. and Dalla-Favera, R. 2004. The BCL6 proto-oncogene suppresses p53 expression in germinal-centre B cells. Nature 432: 635-639.

Phelps, M., Darley, M., Primrose, J.N., and Blaydes, J.P. 2003. p53-independent activation of the hdm2-P2 promoter through multiple transcription factor response elements results in elevated hdm2 expression in estrogen receptor $\alpha$-positive breast cancer cells. Cancer Res. 63: 2616-2623.

Rocha, S., Martin, A.M., Meek, D.W., and Perkins, N.D. 2003. p53 represses cyclin D1 transcription through down regulation of Bcl-3 and inducing increased association of the p52 NF-кB subunit with histone deacetylase 1. Mol. Cell. Biol. 23: 4713-4727.

Ryan, K.M., Ernst, M.K., Rice, N.R., and Vousden, K.H. 2000. Role of NF-кB in p53-mediated programmed cell death. $\mathrm{Na}$ ture 404: 892-897.

Schwarz, E.M., Krimpenfort, P., Berns, A., and Verma, I.M. 1997. Immunological defects in mice with a targeted disruption in Bcl-3. Genes \& Dev. 11: 187-197.

Slack, A., Chen, Z., Tonelli, R., Pule, M., Hunt, L., Pession, A., and Shohet, J.M. 2005. The p53 regulatory gene MDM2 is a direct transcriptional target of $\mathrm{MYCN}$ in neuroblastoma. Proc. Natl. Acad. Sci. 102: 731-736.

Suzuki, K., Yokoyama, S., Waseda, S., Kodama, S., and Watanabe, M. 2003. Delayed reactivation of p53 in the progeny of cells surviving ionizing radiation. Cancer Res. 63: 936-941.

Tergaonkar, V., Pando, M., Vafa, O., Wahl, G., and Verma, I. 2002. p53 stabilization is decreased upon NFкB activation: $A$ role for NFkB in acquisition of resistance to chemotherapy. Cancer Cell 1: 493-503.

Thornburg, N.J., Pathmanathan, R., and Raab-Traub, N. 2003. Activation of nuclear factor-кB p50 homodimer/Bcl-3 complexes in nasopharyngeal carcinoma. Cancer Res. 63: 82938301.

Viatour, P., Bentires-Alj, M., Chariot, A., Deregowski, V., de Leval, L., Merville, M.P., and Bours, V. 2003. NF-к B2/p100 induces Bcl-2 expression. Leukemia 17: 1349-1356.

Viatour, P., Dejardin, E., Warnier, M., Lair, F., Claudio, E., Bureau, F., Marine, J.C., Merville, M.P., Maurer, U., Green, D., et al. 2004. GSK3-mediated BCL-3 phosphorylation modulates its degradation and its oncogenicity. Mol. Cell 16: 3545.

Villunger, A., Michalak, E.M., Coultas, L., Mullauer, F., Bock, G., Ausserlechner, M.J., Adams, J.M., and Strasser, A. 2003. p53- and drug-induced apoptotic responses mediated by BH3-only proteins puma and noxa. Science 302: 1036-1038.

Vousden, K.H. and Lu, X. 2002. Live or let die: The cell's response to p53. Nat. Rev. Cancer 2: 594-604.

Vousden, K.H. and Prives, C. 2005. P53 and prognosis: New insights and further complexity. Cell 120: 7-10.

Wan, Y.Y. and DeGregori, J. 2003. The survival of antigenstimulated T cells requires NFKB-mediated inhibition of $\mathrm{p} 73$ expression. Immunity 18: 331-342.

Watanabe, N., Wachi, S., and Fujita, T. 2003. Identification and characterization of BCL-3-binding protein: Implications for transcription and DNA repair or recombination. J. Biol. Chem. 278: 26102-26110.

Webster, G.A. and Perkins, N.D. 1999. Transcriptional cross talk between NF-кB and p53. Mol. Cell Biol. 19: 3485-3495.

Wessells, J., Baer, M., Young, H.A., Claudio, E., Brown, K., Siebenlist, U., and Johnson, P.F. 2004. BCL-3 and NF-кB р50 attenuate lipopolysaccharide-induced inflammatory responses in macrophages. J. Biol. Chem. 279: 49995-50003.

Westerheide, S.D., Mayo, M.W., Anest, V., Hanson, J.L., and Baldwin Jr., A.S. 2001. The putative oncoprotein Bcl-3 induces cyclin D1 to stimulate G(1) transition. Mol. Cell. Biol. 21: 8428-8436.

Yu, J., Zhang, L., Hwang, P.M., Kinzler, K.W., and Vogelstein, B. 2001. PUMA induces the rapid apoptosis of colorectal cancer cells. Mol. Cell 7: 673-682.

Zhang, Y., Xiong, Y., and Yarbrough, W.G. 1998. ARF promotes MDM2 degradation and stabilizes p53: ARF-INK4a locus deletion impairs both the $\mathrm{Rb}$ and $\mathrm{p} 53$ tumor suppression pathways. Cell 92: 725-734. 


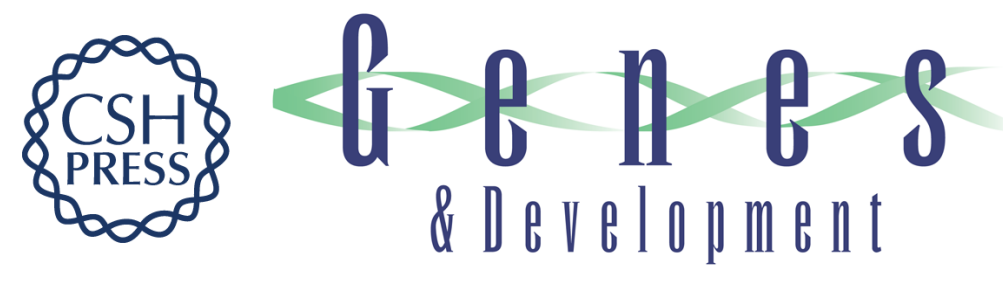

\section{Expression of the $\mathrm{Bcl}-3$ proto-oncogene suppresses p53 activation}

David Kashatus, Patricia Cogswell and Albert S. Baldwin

Genes Dev. 2006, 20:

Access the most recent version at doi:10.1101/gad.1352206

Supplemental
Material http://genesdev.cshlp.org/content/suppl/2005/12/29/gad.1352206.DC1

References This article cites 53 articles, 23 of which can be accessed free at: http://genesdev.cshlp.org/content/20/2/225.full.html\#ref-list-1

License

Email Alerting Receive free email alerts when new articles cite this article - sign up in the box at the top Service right corner of the article or click here.

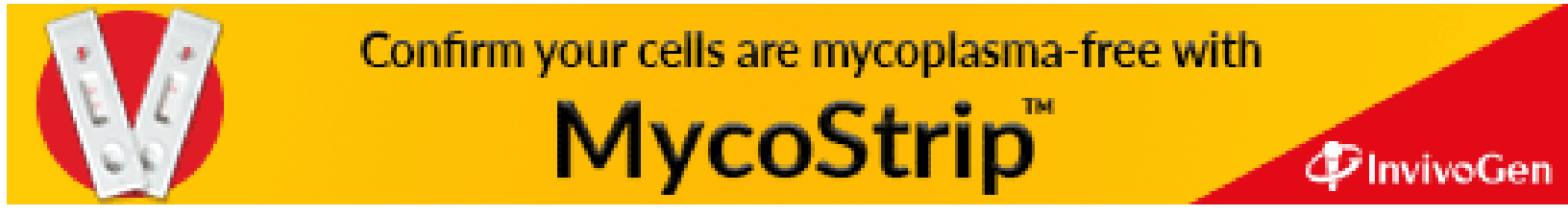

